\title{
IMPLEMENTASI MODEL STUDENT TEAMS ACHIEVEMENT DIVISIONS (STAD) UNTUK MENINGKATKAN KETERAMPILAN READING AND WRITING BAHASA INGGRIS PADA SISWA KELAS XII.IPA.2 SMAN 6 KOTA JAMBI TAHUN PELAJARAN 2018/2019
}

\author{
ACENDRA \\ SMA Negeri 6 Kota Jambi, Provinsi Jambi \\ Email : mandatkami@gmail.com
}

\begin{abstract}
ABSTRAK
Penelitian ini merupakan Penelitian Tindakan Kelas (PTK) yang bertujuan untuk meningkatkan hasil belajar siswa dalam mata pelajaran bahasa Inggris, terutama keterampilan reading dan writing kelas XII.IPA.2 SMAN 6 Kota Jambi yang berjumlah 35 siswa. Penelitian tindakan kelas dilakukan dengan melakukan 4 langkah, yaitu perencanaan, pelaksanaan, observasi, dan refleksi. Penelitian ini dilaksanakan dalam 2 (dua) siklus. Siklus I dan II masing-masing terdiri dari tiga pertemuan. Data penelitian dikumpulkan melalui beberapa instrumen yaitu lembar observasi, catatan lapangan, kuisioner dan penilaian akhir siswa. Berdasarkan hasil penelitian, didapatkan hasil bahwa keterampilan reading dan writing diperoleh nilai dari tindakan dalam siklus menunjukkan bahwa secara umum terjadi kenaikan dari siklus I ke siklus II. Nilai tertinggi naik dari 85 menjadi 90. Nilai terendah naik dari 65 menjadi 70. Nilai rata-rata kelas naik dari 76,5\% menjadi 80,4\%. Presentase ketuntasan belajar klasikal siklus I dan siklus II telah memenuhi ketuntasan klasikal minimal 75\% dengan KKM 75 yang merupakan salah satu kriteria keberhasilan PTK dan terjadi kenaikan dari 80,63\% menjadi 81\%.
\end{abstract}

Kata Kunci: student teams achievement divisions, reading and writing, Bahasa inggris

\section{PENDAHULUAN}

Pembelajaran bahasa mempunyai fungsi sebagai sarana untuk mengembangkan kemampuan berpikir, mengungkapkan gagasan, menyampaikan informasi mengenai suatu peristiwa, serta memperluas wawasan. Pembelajaran Bahasa dan Sastra bertujuan meningkatkan dan mengembangkan keterampilan berbahasa dan bersastra peserta didik yang meliputi keterampilan menyimak, berbicara, membaca, dan menulis (Cahyaningrum, Andayani, Saddhono, 2018:45).

Adapun bahasa Inggris di Indonesia menjadi bahasa asing pertama yang wajib dipelajari dan dikuasai oleh berbagai pihak khususnya para pelajar. Bahasa Inggris dipelajari oleh pelajar dari tingkat pendidikan anak usia dini sampai pada tingkat universitas. Menyadari akan pentingnya bahasa Inggris, maka pemerintah Indonesia memberikan prioritas terhadap bahasa Inggris sebagai bahasa asing pertama yang wajib diajarkan di Indonesia. Ada 4 ketrampilan berbahasa dalam mempelajari bahasa Inggris yaitu mendengarkan (listening), berbicara (speaking), membaca (reading), dan menulis (writing).

Pada Kurikulum SMA pelajaran bahasa Inggris mengajarkan tentang keempat skill tersebut mulai dari kelas X sampai dengan kelas XII, dengan harapan siswa akan lebih kreatif lagi dalam berbahasa Inggris baik secara oral maupun tulisan. Berdasarkan pengalaman penelitidan hasil wawancara dengan siswa, ternyata mereka sering menghadapi kesulitan dalam penulisan. Menurut Solahudin (2003: 19) ada beberapa hal yang harus mendapat perhatian dalam belajar membaca dan menulis bahasa Inggris, diantaranya adalah berkaitan dengan persoalan teknis seperti kekeliruan dalam pemakaian preposition atau conjuction. Kadangkala masih banyak kesalahan pada text yang mereka tulis, mulai pemilihan kata-kata, tata bahasa yang tidak sesuai dengan aturan penulisan, sampai pada makna yang sulit dipahami bagi pembaca. Semua itu karena rendahnya kreativitas yang siswa miliki dan juga pengetahuan menulis bahasa yang digunakan bukan merupakan bahasa sendiri. Kreativitas siswa yang rendah menyebabkan ketidaktertarikan terhadap kegiatan reading and writing yang juga 
berakibat pada aktivitas yang membosankan, karena kurangnya pengetahuan dalam proses membaca dan menulis.

Salah satu ketrampilan berbahasa yang wajib dipelajari dan dikuasai oleh siswa adalah Reading Skill. Menurut Urquhart dan Weir (dalam Grabe, 2009) "reading is process of receiving and interpreting information encoded in language from via the medium of print". Artinya bahwa ada proses pemerolehan informasi yang terjadi setelah melakukan kegiatan proses membaca pada saat itu. Mengenai reading skill, menulis (reading) merupakan sebuah kegiatan berlangsungnya sebuah proses memperoleh dan menginterpretasikan sebuah informasi yang berlangsung di dalam otak. Pada saat proses belajar mengajar Reading skill, tidak selamanya kegiatan tersebut membuat siswa merasa nyaman dan senang dalam mengikuti proses belajar mengajar. Hal tersebut bisa jadi disebabkan oleh kemampuan siswa yang terbatas dalam memahami teks berbahasa Inggris. Ketidakmampuan tersebut menjadi suatu hambatan yang berdampak terhadap banyak hal, antara lain mudah merasa bosan manakala proses belajar mengajar Reading skill berlangsung, kurangnya perbendaharaan kata dalam bahasa Inggris, terlalu pasif dalam proses belajar mengajar, kurangnya motivasi dalam proses belajar mengajar Reading skill. (Widyahening, 2018: 11-19).

Adapun menulis (writing) merupakan tingkat keterampilan berbahasa yang paling tinggi dibandingkan dengan keterampilan berbahasa lainnnya. Keterampilan menulis sebagai sebuah kompetensi linguistic verbal membutuhkan dukungan keterampilan berbahasa lainnya, seperti berbicara, menyimak, dan membaca. Menulis merupakan proses menuangkan ide, pendapat, dan pikiran untuk disampaikan kepada orang lain. (Magdalena, 2017: 194-203). Menulis (wiriting) merupakan keterampilan berbahasa Inggris yang mempunyai peranan yang sangat penting, baik dalam komunikasi formal maupun komunikasi informal. Skill ini adalah alat bagi seseorang untuk berkomunikasi dan mengekspresikan dirinya. Menurut Silberman (2000: 124) menulis merupakan proses berpikir sehingga bagi seseorang yang banyak menulis pikirannya akan menjasi lebih tajam. Keterampilan menulis itu akan tumbuh, bila semakin banyak berlatih dan akan semakin tinggi keterampilannya dalam menulis pikirannya akan lebih tajam. Keterampilan menulis bila semakin banyak berlatih akan semakin mahir dalam menyampaikan apa yang menjadi buah pikirannya. Tujuan dari menulis adalah agar tulisan yang dibuat dapat dibaca dan dipahami oleh orang lain yang mempunyai kesamaan pengertian terhadap bahasa yang dipergunakan. Hakikat menulis merupakan suatu proses kreatif memindahkan gagasan kedalam lambang-lambang tulisan. Hal ini sesuai dengan yang diungkapkan oleh Tarigan (1993) "menulis adalah menurunkan atau melukiskan lambang-lambang grafik yang menggambarkan suatu bahasa yang dipahami oleh seseorang sehingga orang lain dapat membaca lambang-lambang grafik tersebut". Dalam pengajaran bahasa, keterampilan menulis merupakan salah satu cara menyampaikan maksud dan tujuan dengan cara tertulis yang merupakan kemampuan peserta didik untuk mengekspresikan maksud melalui media bahasa. Demikian juga pada pengajaran sastra, menulis merupakan puncak kemampuan untuk menyatakan maksud, rasa, dan pikiran secara kreatif.

Metode dan model pembelajaran yang konvensional, tidak kreatif, kurang inovatif dan terbatasnya media yang digunakan menjadi penyebab utama siswa enggan dan sulit mengerti dan mengikuti pelajaran bahasa Inggris. Oleh karena itu sudah saatnya guru mulai menggunakan metode dan model pembelajaran yang lebih variatif dan inovatif dalam pembelajaran untuk meningkatkan hasil belajar siswa.

Beberapa permasalahan yang kongkret yang dihadapi oleh pembelajar bahasa Inggris pada khususnya proses pembelajaran menulis dikelas adalah sebagai berikut : 1) Ketika siswa mulai menulis paragraf dan berbicara, mereka kurang biasa mengkaitkan gagasan yang ada yang berakibat pada lemahnya text yang ditulis dan percakapan yang dilakukan dari sudut uniti dan koherensi.2). Siswa masih lemah dalam pengorganisasian informasi kedalam teks yang akurat secara order dan penggunakan transition signal yang tidak tepat baik hasil text yang mereka tulis ataupun ketika berbicara akan sulit dipahami oleh pembaca. 3) Kebanyakan siswa masih miskin ide dan imaginasi untuk dikembangkan ke dalam tulisan. 4) Motivasi yang rendah 
seperti rendahnya kesadaran akan kewajiban belajar siswa, kurang aktif dalam mengikuti proses pembelajaran, kurang antusias dalam mempelajari bahasa Inggris, kurang adanya usaha untuk mengerjakan tugas secara mandiri, serta kondisi lingkungan belajar yang kurang kondusif.

Berdasarkan hasil wawancara terhadap siswa kelas XII.IPA.2 SMA Negeri 6 Kota Jambi, ditemukan bahwa faktor kepercayaan diri yang menghambat peserta didik untuk menuangkan ide-ide yang ada dalam bentuk tulisan. Kepercayaan diri itu diantaranya karena kurang menguasai kosakata dan kurang memahami struktur bahasanya. Selain itu model yang digunakan guru cenderung membosankan.

Berdasarkan uraian di atas, maka terdapat beberapa kesenjangan antara harapan dan kenyataan yang ada. Untuk menghilangkan kesenjangan itu harus ada usaha yang efektif agar proses pembelajaran menjadi berkualitas agar mampu meningkatkan antusias siswa untuk belajar dengan baik sehingga tercapai tujuan pembelajaran yang diharapkan. Proses pembelajaran yang dilakukan dengan pengelolaan pembelajaran yang menggunakan modelmodel pembelajaran yang tepat dengan melibatkan siswa secara langsung agar memperoleh pembelajaran yang optimal sehingga meningkatkan hasil belajar bahasa Inggris siswa. Alternatif solusi yang diharapkan yang diharapkan dapat meningkatkan hasil belajar Bahasa Inggris siswa kelas XII.IPA.2 SMA Negeri 6 Kota Jambi adalah menggunakan model pembelajaran kooperatif STAD (Student Teams Achievement Divisions) dengan model ini diharapkan akan merangsang otak siswa untuk lebih kreatif menulis. Model pembelajaran kooperatif tipe Student Team Achievement Division(STAD) merupakan salah satu alternatif model pembelajaran yang dapat diterapkan dalam pembelajaran Bahasa Inggris. Model pembelajaran ini mengajak siswa bekerja sama dalam sebuah kelompok untuk memecahkan persoalan yang mereka hadapi. Guru membagi kelas menjadi kelompok-kelompok yang heterogen untuk meminimalisir terjadinya kesenjangan antarsiswa. Selama kegiatan kelompok berlangsung, guru membimbing setiap kelompok berdiskusi. (Mardiana, 2019: 13-19). Dijelaskan lagi bahwa Pembelajaran yang mengembangkan prinsip kerjasama akan mampu memberikan gambaran solusi bagi siswa dalam menemukan pemecahan masalah pembelajaran dengan cara berkelompok. Adapun model pembelajaran yang tepat tersebut adalah pembelajaran metode STAD (Students Teams Achievement Division). Prinsip dari metode STAD ini adalah kerjasama peserta didik dalam tim, bagaimana mereka membentuk sebuah kerja tim yang mampu memecahkan sebuah masalah secara bersama-sama tanpa meninggalkan anggota tim yang memiliki kemampuan rendah. Mereka berbagi dan tumbuh bersama (Let's sharing and Growing together). (Sastri, 2020: 132-145). Karakteristik STAD dapat dikategorikan sebagai berikut: 1) tim biasanya terdiri dari empat orang yang digabungkan berdasarkan jenis kelamin, kemampuan dan etnik yang berbeda. 2) guru mempresentasikan materi pembelajaran dan siswa belajar dalam kelompoknya untuk meyakinkan bahwa semua anggota telah mencapai tujuan pembelajaran. 3) siswa mendapat kuis berkaitan dengan materi saat itu. 4) penilaian dirata-ratakan untuk setiap tim dan dibandingkan dengan skor terdahulu. 5) tim yang mencapai kriteria tertentu diberi penghargaan. (Firdaus, 2017: 17). Siswa dapat lebih tertarik dengan mudah mempelajari dan memahami sebuah cerita atau topik untuk menulis cerita dalam bahasa Inggris sehingga siswa dengan mudah dan akan lebih antusias terlibat aktif dalam pembelajaran dan mendapat pengalaman pembelajaran baik secara individu maupun kelompok yang akan meningkatkan kemampuan akademis. Untuk membuktikan alternatif solusi tersebut mampu meningkatkan kemampuan hasil belajar Bahasa Inggris siswa maka dilakukan suatu Penelitian Tindakan Kelas (PTK), yaitu pengelolaan pembelajaran dengan menerapkan Model Student Teams Achievement Divisions untuk meningkatkan hasil belajar bahasa Inggris pada siswa kelas XII.IPA.2 SMA Negeri 6 Kota Jambi. 
Penelitian tindakan kelas ini dilaksanakan pada semester I (ganjil) Tahun Pelajaran 2018/2019 sekitar tiga bulan mulai dari bulan Agustus sampai bulan Oktober 2018. Subjek penelitian ini yang terdiri dari dua guru sebagi model (guru Mata Pelajaran Bahasa Inggris) dan siswa kelas XII.IPA.2 yang berjumlah 35 siswa semester ganjil (1) tahun pelajaran 2018/2019 di SMA Negeri 6 Kota Jambi. Metode penelitian ini menggunakan Penelitian Tindakan Kelas (PTK).

Analisis data dari siklus I dan siklus II dilakukan secara deskriptif dengan menggunakan teknik prosentase untuk melihat kecenderungan yang terjadi dalam kegiatan belajar mengajar $(\mathrm{KBM})$. Data penelitian diperoleh dengan cara observasi, wawancara, tes dan catatan lapangan.

\section{HASIL DAN PEMBAHASAN}

Berdasarkan data yang diperoleh dari siklus 1 dan 2 menemukan bahwa hasil pengamatan aktifitas/antusiame siswa pada siklus 1 dan 2 yang diamati oleh observer selama 4 pertemuan dalam 2 siklus dihasilkan nilai secara rinci yang divisualisasikan pada tabel dan grafik di bawah ini:

Tabel 1. Persentase On dan Off Task

\begin{tabular}{ccccc}
\hline siklus & \multicolumn{2}{l}{ Tindakan1 } & \multicolumn{2}{c}{ Tindakan2 } \\
& Off & On & Off & On \\
& task & task & task & task \\
1 & 9,52 & 85,4 & 7,94 & 89,2 \\
2 & 8,52 & 88,9 & 6,98 & 90,2 \\
\hline
\end{tabular}

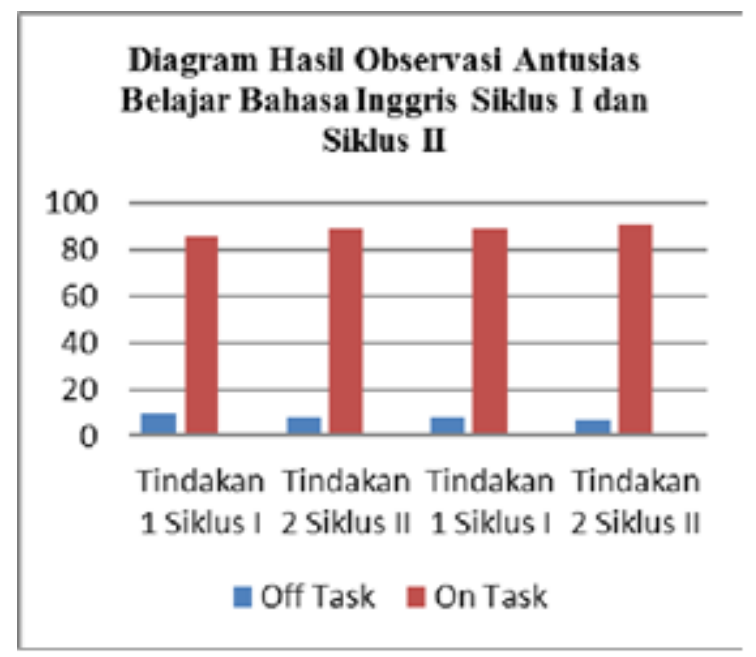

Gambar 1. Antusiasme belajar siswa

Rekapitulasi hasil observasi terhadap antusias belajar siswa menunjukkan bahwa pada setiap tindakan baik siklus I maupun siklus II, sebagian besar siswa bersemangat dan terlibat secara aktif mengikuti kegiatan pembelajaran, hal ini ditunjukkan dengan angka presentase on task yang masuk dalam kategori sangat tinggi, yaitu berada pada rentang 80-100. Siswa banyak menunjukkan sikap positif terhadap kegiatan pembelajaran daripada sikap yang negatif yang tentu saja akan merugikan diri mereka sendiri.

Menurut Rusman (2012:204) konsep utama dari belajar kooperatif/ Cooperative Learning adalah teknik pengelompokkan yang didalamnya siswa bekerja terarah pada tujuan belajar bersama dalam kelompok kecil yang umumnya terdiri dari 4 orang siswa. Belajar Cooperative Learning adalah pemanfaatan kelompok kecil dalam pembelajaran yang memungkinkan siswa bekerja bersama untuk memaksimalkan belajar mereka dan belajar anggota lainnya dalam kelompok tersebut. Cooperative Learning atau pembelajaran kooperatif bertujuan untuk menciptakan lingkungan yang positif di mana orang belajar untuk bekerja bersama untuk mencapai tujuan bersama. Model ini bertujuan untuk menciptakan lingkungan 


\section{LANGUAGE : Jurnal Inovasi Pendidikan Bahasa dan Sastra Vol 1. No 1. Agustus 2021, e-ISSN : 2807-1670 | p-ISSN : 2807-2316}

kerja yang positif dan mengembangkan kerjasama dan pemahaman orang lain sebagai individu yang belajar bersama. Model ini juga digunakan untuk melengkapi bentuk-bentuk lain dari instruksi dengan memberikan kesempatan kepada siswa untuk belajar satu sama lain, berdiskusi dalam kelompok atau dimasukkan ke dalam keterampilan praktek atau informasi yang disajikan oleh instruktur. Di dalam setiap kelompok masing-masing anggota mempunyai gagasan untuk memotivasi antar anggotanya dan saling membantu agar tercapai suatu tujuan pembelajaran yang maksimal.

Menurut pendapat Salvin yang dikutip oleh Trianto (2010:61), konsep utama dari belajar Kooperatif adalah : (a) Penghargaan kelompok, yang akan diberikan jika kelompok mencapai kriteria yang ditentukan. (b) Tanggung jawab individual, bermakna bahwa suksesnya kelompok tergantung pada belajar individual semua anggota kelompok. Tanggung jawab ini terfokus dalam usaha untuk membantu yang lain dan memastikan setiap anggota kelompok telah siap menghadapi evaluasi tanpa bantuan yang lain. (c) Kesempatan yang sama untuk sukses, bermakna bahwa siswa telah membantu kelompok dengan cara meningkatkan belajar mereka sendiri. Hal ini memastikan bahwa setiap siswa dengan kemampuan yang berbeda sama-sama tertantang untuk melakukan yang terbaik dan bahwa semua anggota kelompok sangat bernilai.

Tindakan 1, aktivitas guru ditemukan beberapa hal yang tidak dilakukan saat langkahlangkah pembelajaran yaitu; (1) guru tidak menjelaskan tujuan pembelajaran, (2) guru tidak memberikan waktu untuk siswa bertanya saat penjelasan materi, (3) guru tidak membimbing saat diskusi dan (4) guru tidak memberikan umpan balik. Adapun yang perlu diperbaiki diantaranya; 1) pemahaman langkah-langkah pembelajaran, (2) penjelasan materi tidak terburuburu, (3) guru membimbing siswa dan berbaur, dan (4) memberikan umpan balik kepada siswa. Pengamatan pada tindakan 2, ditemukan guru sudah memperbaiki beberapa hal yang terjadi pada tindakan 1, akan tetapi masih ada kekurangan mengenai umpan balik yang kurang mendalam.

Pada siklus 2 tindakan 1, berdasarkan hasil pengamatan terhadap aktivitas guru ditemukan beberapa hal yang perlu diperbaiki yaitu guru lebih berbaur dengan siswa saat proses diskusi. Pengamatan pada tindakan 2, ditemukan guru sudah memperbaiki hal yang terjadi pada tindakan 1.Aktivitas yang dilakukan oleh guru yang telah tertuang di RPP dalam langkahlangkah pembelajaran dari mulai siklus 1 pada tindakan 1, masih terdapat kekurangan dan ada beberapa kegiatan yang tidak dilakukan. Namun, pada tindakan 2 ada perbaikan langkahlangkah pembelajaran yang telah dilaksanakan oleh guru. Dalam siklus 1 langkah pembelajaran yang belum optimal dilakukan oleh guru ialah proses pembimbingan saat diskusi dan pemberian umpan balik kepada siswa. Pengalaman pengunaan model dan media yang berbeda mengharuskan guru untuk menghafal dan menjalani secara berulang agar pelaksanaan pembelajaran optimal. Proses pelaksanaan pembelajaran yang dilakukan oleh guru model dalam siklus 1 butuh pengalaman yang sering untuk menjalankan pelaksanaan model pembelajaran STAD di kelas XII.IPA.2 SMA Negeri 6 Kota Jambi.

Hasil pengalaman siklus 1, pada aktivitas guru dalam siklus 2 memiliki peningkatan yang baik dalam melaksanakan langkah-langkah pembelajaran sudah lancar dan terbiasa. Menurut Muhibin, menyatakan belajar ialah perolehan perubahan tingkah laku yang yang relatif menetap sebagai akibat latihan dan pengalaman. Pengunaan model pembelajaran STAD merupakan komponen model yang berbeda menjadi kesatuan langkah-langkah pembelajaran di kelas, hal tersebut membutuhkan pemahaman dan pengalaman dalam melakukan pelaksanaan pembelajaran untuk mengasah keterampilan dalam mengajar.

Kemampuan yang diperoleh siswa sebagai hasil belajar bahasa Inggris meliputi hasil belajar reading dan writing. Hasil pengolahan dan analisis data kedua hasil belajar pada penelitian ini disajikan sebagai berikut : 


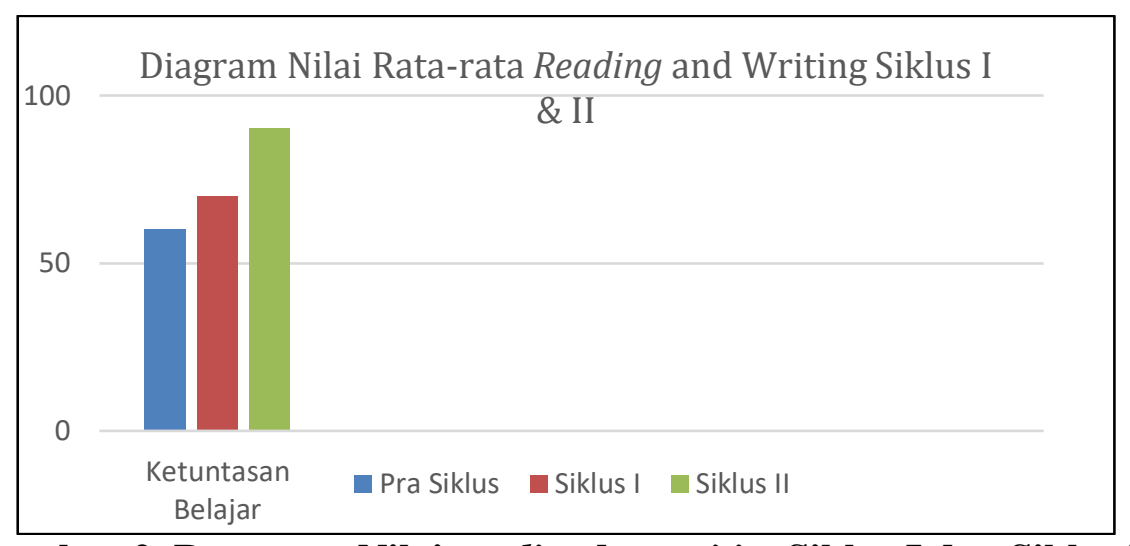

Gambar 2. Rata-rata Nilai readingdan writingSiklus I dan Siklus II

Hasil belajar keterampilan reading dan writing pada siklus 1 menunjukan bahwa kecapaian keberhasilan perolehan hasil belajar perlu ditingkatkan. Kegiatan pembelajaran yang dilakukan dan perhatian guru saat pelaksanaan pembelajaran amat penting untuk membantu siswa dalam menyerap materi ajar dengan baik. Media pembelajaran dapat memotivasi antusiasme siswa saat pembelajaran di dalam kelas, terbukti dari hasil belajar siklus 2 yang mengalami peningkatan hasil belajar.

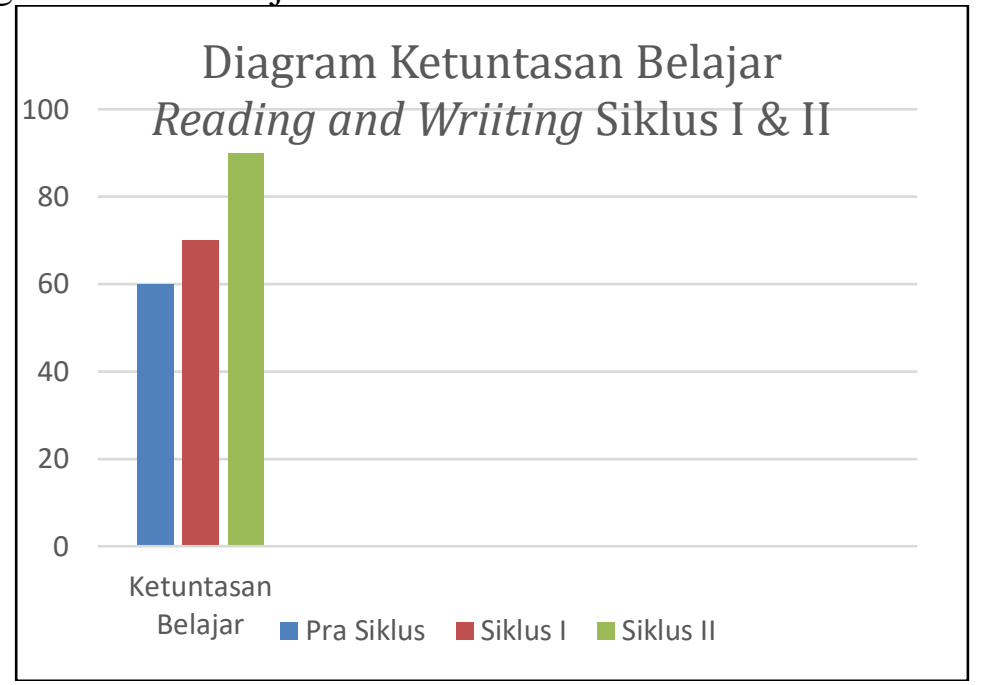

\section{Gambar 3. Ketuntasan Nilai Reading dan writing Siklus I dan Siklus II}

Data hasil belajar keterampilan reading dan writing diperoleh nilai dari dua tindakan dalam satu siklus menunjukkan bahwa secara umum terjadi kenaikan dari siklus I ke siklus II. Nilai tertinggi naik dari 85 menjadi 90. Nilai terendah naik dari 65 menjadi 70. Nilai rata-rata kelas naik dari 76,5\% menjadi $80,4 \%$. Presentase ketuntasan belajar klasikal siklus I dan siklus II telah memenuhi ketuntasan klasikal minimal $75 \%$ dengan KKM 75 yang merupakan salah satu kriteria keberhasilan PTK dan terjadi kenaikan dari 80,63\% menjadi $81 \%$.

Menurut Reece dan Walker (1997: 254) pembelajaran pada ranah psikomotor meliputi aspek psiko (aspek kognitif yang harus diingat dan dimengerti) dan aspek motor, aspek gerakan dan koordinasi antara otak dan anggota badan (biasanya, tapi tidak selalu, tangan).

Dari semua kajian teori-teori dan data-data yang diambil selama penelitian ini, maka dapat ditarik sebuah kesimpulan bahwa model pembelajaran STAD dapat meningkatkan hasil belajar siswa dalam bahasa Inggris yang meliputi keterampilan reading dan wiriting. 
Berdasarkan hasil analisis data, temuan penelitian, dan refleksi setiap siklus, maka Penelitian Tindakan Kelas (PTK) dengan mengimplementasikan model pembelajaran kooperatif STAD pada pembelajaran Bahasa Inggris menghasilkan kesimpulan sebagai berikut : (1) Pengelolaan pembelajaran dengan model pembelajaran kooperatif STAD (Student Teams Achievement Divisions) dapat meningkatkan hasil belajar bahasa Inggris siswa kelas XII.IPA.2 SMA Negeri 6 Kota Jambi. Hal ini dapat dibuktikan dengan hasil yang didapat selama melakukan penelitian tindakan kelas dengan terpenuhinya kriteria keberhasilan PTK dan mengalami peningkatan dari silus I ke siklus II. Presentase ketuntasan klasikal hasil belajar reading naik dari $80,63 \%$ menjadi $81 \%$, dan rata-rata hasil belajar writing naik dari $77,94 \%$ menjadi $81 \%$. (2) Pengelolaan pembelajaran dengan model pembelajaran kooperatif STAD (Student Teams Achievement Divisions) dalam kegiatan proses pembelajaran mempunyai urutan-urutan sebagai berikut: (a). Tahap persiapan, (b). skor perkembangan individu, dan (f). Tahap penghargaan kelompok. Tahap penyajian materi, (c). Tahap kegiatan kelompok, (d). Tahap pelaksanaan tes individu, (e). Tahap perhitungan Kedua model pembelajaran ini mampu meningkatkan antusias siswa untuk terlibat secara aktif dalam pembelajaran baik secara fisik maupun psikis, meningkatkan komitmen siswa, siswa terbiasa bersaing secara sehat, dapat meningkatkan kemampuan berkomunikasi untuk menyampaikan informasi, ide dan pendapat, serta meningkatkan kemampuan akademis baik individu maupun kelompok yang akhirnya dapat meningkatkan hasil belajar siswa. (3) Pelaksanaan model pembelajaran kooperatif dengan model pembelajaran STAD berhasil memberikan solusi dalam meningkatkan antusiame dan peran aktif siswa dalam kegiatan pembelajaran di dalam kelas yang berdampak dengan meningkatnya hasil belajar siswa dalam keterampilan reading dan writing.

\section{DAFTAR PUSTAKA}

Cahyaningrum, F., Andayani, Kundharu Saddhono. (2018). Peningkatan Keterampilan Menulis argumentasi Melalui Model Think Pair Share dan Media Audiovisual Pada Siswa Kelas X-10 SM Negeri Kebakkramat. Jurnal Pendidikan dan Kebudayaan, 2(1):45.

Firdaus, F. (2017). Penerapan Model Pembelajaran Cooperative Learning Tipe Stad Untuk Meningkatkan Kemampuan Membaca Pemahaman Bahasa Inggris. Jurnal Penelitian Pendidikan, 17(1).

Grabe, William. 2009. Reading in a Second Language: Moving from Theory to Practice. Cambridge: Cambridge University Press.

Magdalena, R. (2017). Peningkatan Keterampilan Menulis Ringkasan Teks Bacaan Melalui Model Pembelajaran Teknik CIRC (Cooperative Integrated Reading Composition). Deiksis, 9(02), 194-203.

Mardiana, M. (2019). Penerapan Metode STAD untuk Meningkatkan Motivasi dan Hasil Belajar Bahasa Inggris di Kelas XI IPA. 3 SMA Negeri 1 Bandar Baru. Jurnal Sosial Humaniora Sigli, 2(1), 13-19.

Reece, Ian danWalker, Stephen. (1997). Teaching,Training, and Learning. Sunderland:Business Education Publisher Limited.

Rusman. (2012). Model-Model Pembelajaran Mengembangkan Profesionalisme Guru. Jakarta: PT. RajaGrafindo Persada.

Sastri, N. (2020). PENGGUNAAN METODE STAD (STUDENT TEAMS ACHIEVMENT DIVISION) DALAM MENINGKATKAN HASIL UJIAN NASIONAL PELAJARAN BAHASA INGGRIS PADA SISWA SMK SMAK PADANG. In Prosiding Seminar Nasional Ahlimedia (Vol. 1, No. 1, pp. 132-145).

Silberman,Mel. (2000). Active Learning .Printed in the United States of America.

Solahudin, M. (2003). Tutorial Writing Bahasa Inggris . Yogyakarta: Berlian

Tarigan, Henry Guntur (1993). MenulisSebagai Suatu Keterampilan. Bandung: Angkasa.

Trianto. (2010). Mendesain Model Pembelajaran Inovatif-Progressive. Jakarta: Kencana Prenada Media Group. 
Widyahening, C. E. (2018). Penggunaan Teknik Pembelajaran Fishbone Diagram Dalam Meningkatkan Keterampilan Membaca Siswa. Jurnal Komunikasi Pendidikan, 2(1), $11-19$. 